\title{
LANDSCAPE OF CULTURAL IDENTITY AT RUMAH MAKAN MINANG
}

\author{
Oktavianus \\ Fakultas Ilmu Budaya, Universitas Andalas \\ Kampus Limau Manis Padang, Indonesia \\ (oktavianus@hum.unand.ac.id) \\ DOI: https://doi.org/10.22452/jati.vol24no2.9
}

\begin{abstract}
Every ethnic group in the world has its own cultural identity. It marks the characteristic and indicates the uniqueness of a particular ethnic group. The landscape of cultural identity is very complex and dynamic. Continuous studies are needed. This research is an attempt to investigate the landscape of cultural identity of one ethnic group in Indonesia. The research is conducted on Rumah Makan Minang (RM Minang) - the culinary business of Minangkabau people of West Sumatera. The signs used at RM Minang are assumed to represent cultural identities. The data for this research is taken from RM Minang in Sumatera, Java, Bali, Lombok, Sulawesi, Papua and Kuala Lumpur. The analysis of data is conducted from the perspective of the linguistic and nonlinguistic landscape through a multimodal approach. In terms of the form, the result of the analysis indicates that the landscape of cultural identity at RM Minang consists of linguistic and nonlinguistic signs marking Minangkabau, national and foreign cultural identity. In terms of design, the landscape of cultural identity at $R M$ Minang always uses different semiotic modes in one text to construct cultural identity.
\end{abstract}

Keywords: landscape, cultural identity, linguistic sign, nonlinguistic sign, Rumah Makan Minang (RM Minang)

\section{Introduction}

The use of language in a broad sense to fulfil human needs and to run their life is very complex. Creative ways of using the language for many purposes at public places can easily be seen around us. Kress and Leeuwen (2001) state that semiotic modes of human communication can include visual, verbal, written, gestural, musical resources, and various multimodal ensembles these modes. In a simple 
category, these semiotic modes can be grouped into linguistic and nonlinguistic signs. None of the activities of human beings can be done without using the language of various modes (Oktavianus \& Revita, 2013, pp. 1-3). Then, Crystal (1998, pp. 11-13) proposed the main functions of language, namely emotional expression, social interaction, control of reality, recording the facts, instrument of thought, and expression of identity. Identity itself can include cultural identity, social identity, and political identity. The language to fulfil those functions is also designed using different semiotic modes.

The focus of this study is to investigate cultural identity through the linguistic landscape and nonlinguistic approach. In this globalised era, the study of cultural identity at RM Minang is multipurpose, first, this research on cultural identity by applying linguistic landscape and multimodal approach is expected to uncover the uniqueness of cultural identity as found at RM Minang. Second, this study is also expected to be able to find out the form of cultural identity at RM Minang. Third, this research is expected to be able to figure out the landscape of cultural identity at RM Minang. Fourth, the meaningful and valuable contribution of this research is the step towards cultural and language maintenance. Preservation of languages in the world is done for the sake of keeping diversity, identity, history, human knowledge and aesthetics of languages (Crystal, 2000, pp. 27-55). The efforts toward investigating and preserving language and culture are essential because language and culture may shift, change and even extinct. Fifth, RM Minang is chosen as the object of the research because it has its own characteristics. RM Minang is familiar with its cultural attributes (see Figure 1).

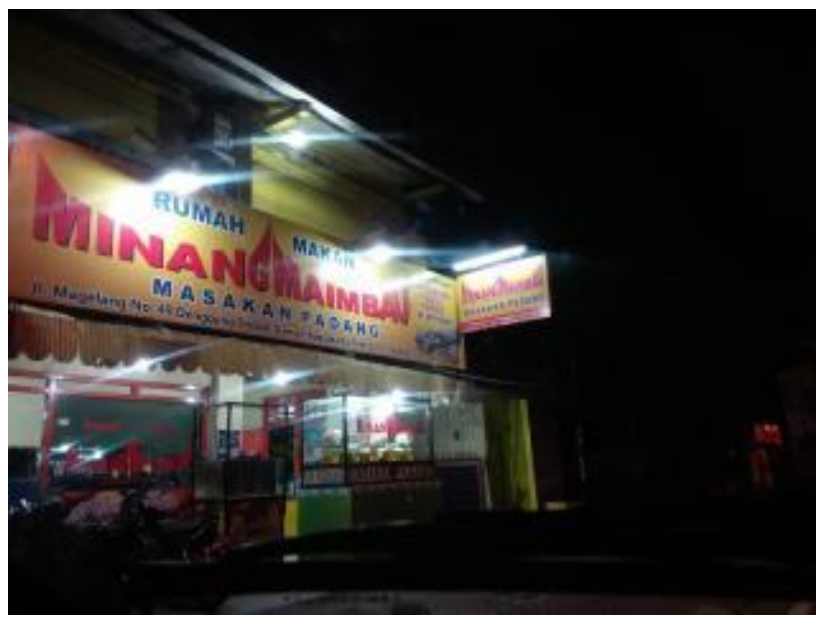

Figure 1: RM Minang Maimbau (Yogyakarta) (Source: Oktavianus, fieldwork, 2018.) 
RM Minang as shown in Figure 1 is located in Yogyakarta. The picture is taken at night. The beautiful design of name plank, Minang Maimbau printed in red colour is decorated with bright lighting. The cultural identity of RM Minang can be seen from the design of the name plank resembling the pointed roof of Minangkabau traditional house. The terms Rumah Gadang and Rumah Adat Minang are commonly used in Minangkabau. This writing prefers to use the term Rumah Adat Minang in order to keep a sense of the cultural word. The comparison between name plank of RM Minang in the above picture with the design of the roof of Rumah Adat Minang as Minangkabau cultural identity can be seen in Figure 2.

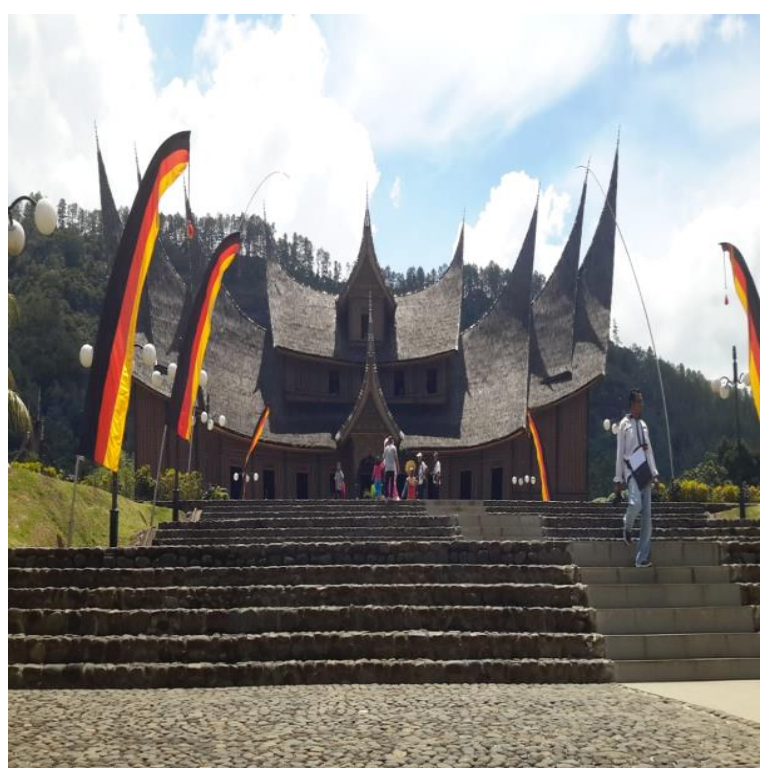

Figure 2: Istano Pagaruyuang Batu Sangkar (Source: Oktavianus, fieldwork, 2018.)

The two pictures above illustrate how plank design of RM Minang Maimbau resembles the pointed roof of Rumah Adat Minang represented by Istano Pagaruyuang in Batu Sangkar.

The examples in Figures 1 and 2, a more in-depth and detail study about cultural identity at RM Minang is needed, which may produce interesting findings. The study is focused on two main themes, namely forms and designs of cultural identity at RM Minang. The two main themes of the research are put under the concept of the landscape which includes linguistic and nonlinguistic landscape. Observing the placement of language at public places, it seems that linguistic signs and nonlinguistic signs are usually combined to form the text 
containing cultural identity. Thus, the focus of the research is to study the landscape of cultural identity at RM Minang, which include various forms and designs of cultural identity.

\section{Literature Review and Theoretical Framework}

The significant part of the use of language as cultural identity is the placement of written language in public spaces. Wherever we go, there are languages around us in public places. We can easily get information related to everything we need. Information about restaurants and rumah makan, banks, toilets, shops of any kinds, schools, bus stations, airports are some of them. The use of language in public places serves as the base to label things and to show cultural identity. The landscape of language use can be defined as " $[t]$ he language of public road signs, advertising billboards, street names, place names, commercial shop signs, and public signs on government buildings combines to form the LL of a given territory, region, or urban agglomeration" (Landry \& Bourhis, 1997, p. 25).

Research related to the use of language at public places under the linguistic landscape approach has much been done. For instance, Amer and Obaidat (2014)'s study examines the role and influence of English in the local language in the business sector through shop signs. The research is both quantitative and qualitative. The results of the research show that the shop signs are dominated by English and Arabic language, which covers almost 58\% of all the languages used for shop signs. The use of English is associated with globalisation, modernity, prestige and for decorative purposes (Amer \& Obeidat, 2014, p. 251). The interesting thing found in their study is that English can improve business. About the designs of language in public place in Aqaba, this research mentions that Arabic names of shops and restaurants are put in English spellings, and Arabic spellings are used to represent English words and phrases (Amer \& Obeidat, 2014, p. 251). However, this study did not investigate the cultural identity of the shop signs.

Research on language at public places was also conducted by Paolo Coluzzi (2012). His study was conducted at one of the main streets in the capital of Brunei Darussalam. There are three languages used which are English, Malay and Chinese with Roman, Arabic and Chinese scripts (Coluzzi, 2012). The choice of language to be placed at the public place is related to the status of language itself. In that research, it is found that minority language does not appear as a linguistic landscape at a public place in the location of the study.

Meanwhile, English and Chinese are used in public places because the two languages are regarded as the high prestige languages. The choice of language is closely related to the symbolic value of the participants (Spolsky, 
2009, p. 33). However, Malay is not regarded as important as English. It is the language of religion, as mentioned by Coluzzi (2012). Malay culture and the teachings of Islam are packed with the Malay language. Coluzzi (2012) studied that linguistic landscape as cultural identity and the designs of language as a cultural identity have not yet been studied in detail.

Fekede and Gamechu conducted a study on the use of language at public places. The focus of the study is on ethnolinguistic vitality of three different languages in Adama, Jimma and Sabata towns. The languages as the object of the study are Afan Omo, Amharic, English and other languages. The study is done on 300 hundred signs in each of the three towns. The main finding of that research is that the dominant use of language in the three towns is Amharic, followed by English. The finding of the research also indicates that English and Afan Omo language play the role of symbolic function.

Meanwhile, Amharic is the language for communication (Fekede \& Gamechu, 2016, p. 8). This is in line with what is stated by Landry and Bourhis (1997, p. 25) that the linguistic landscape of a territory can serve two primary functions named as informational and symbolic functions. The other important finding proposed by Fakede and Gamechu (2016, p. 8) is that the linguistic landscape of the town does not reflect the language spoken by the speech community of Oromia.

This fact that the linguistic landscape at public places does not reflect the language spoken by the speech community can also be seen in Indonesia. Oktavianus (2019) conducted a study entitled "The roles and designs of written English at public places". The data is taken from the different cities like Sumatera, Jawa, Bali, Lombok, Papua and Sulawesi of Indonesia. Written English is dominantly used to name the shops, restaurants, schools, airports, short notices, and others. However, people in public places do not speak English. The language situation in Indonesia is influenced by language policy of the government through Language Development and Fostering Agency of Ministry of Education and Culture (Badan Bahasa Kementerian Pendidikan dan Kebudayaan) The institution responsible for standardising and regulating language use. As the regulator of language use, Language Development and Fostering Agency of Ministry of Education and Culture has the motto Utamakan Bahasa Indonesia 'that prioritise the Indonesian language', Lestarikan Bahasa Daerah 'which preserve local language' Kuasai Bahasa Asing from 'master foreign language'.

Several researchers have conducted research related to RM Minang. The business aspects of RM Minang is one of the essential element. RM Minang is aimed at empowering the economy of Minangkabau local people and those who worked there (Oktavianus, Revita, \& Anwar, 2017). RM Minang in rantau or 
outside of West Sumatera is closely related to temporary migration concept of Minangkabau people (Naim, Paragoan, Asril, \& Rasyid, 1987) and work ethics of Minangkabau people (Amir, 1997). Marantau for Minang people is one of the ways to have a better life. The culinary business at RM Minang is the job mostly occupied by Minang people in rantau. The study about RM Minang is much focused on the philosophy and concept RM Minang which follows ekonomi pancasila (Naim et al., 1987). The study conducted by Oktavianus, Revita, and Anwar (2017) focuses on the variation of names and cultural values. The landscape of cultural identity in terms of the combination between linguistic and nonlinguistic signs has not yet been studied in detail. The construction of cultural identity through linguistic and nonlinguistic signs is the main focus of this study that differentiates this research from the previous researches.

\section{Methodology}

The object of this study is linguistic and nonlinguistic signs indicating cultural identity, whether it is local, national or foreign cultural identity. The data is taken from RM Minang in Sumatera, Jawa, Bali, Lombok, Papua, Sulawesi and Kuala Lumpur. Data is collected by photographing the names, all labels and attributes of RM Minang. The analysis of data is done by applying referential and pragmatic identity methods (Sudaryanto, 2018). In order to know in detail the reasons to use names, labels and attributes as cultural identity, the researcher conducted the interviews and focused group discussions with the owners and consumers of RM Minang and experts in Minangkabau culture.

\section{Findings and Analysis}

\section{The Landscape of Cultural Identity at RM Minang}

Cultural identity can be defined as the markers of belonging to a particular culture. It marks and differentiates one culture from the others. The marker of cultural identity can be in the form of linguistic and nonlinguistic signs. In the case of RM Minang, the linguistic signs as the marker of cultural identity can be seen through the names of the menu as it is in the following data taken from $R M$ Sederhana in Jakarta (Figure 3). 


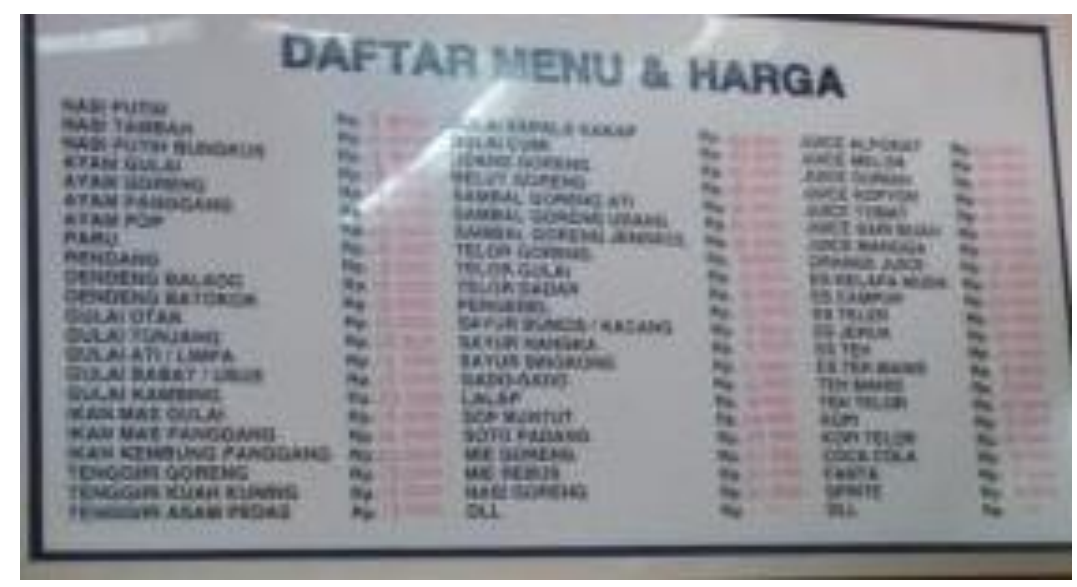

Figure 3: List of menu RM Sederhana Jakarta (Source: Oktavianus, fieldwork, 2018.)

The landscape of cultural identity at RM Minang in the list of the menu above is constructed in three languages, namely Indonesian, Minangkabau and English. Minangkabau cultural identity is marked by three names of the menu, namely dendeng balado, dendeng batokok and gulai ati. Dendeng balado and dendeng batokok are categorised into Minangkabau cultural words because these two concepts cannot be translated fully into the Indonesian language while most of the names of the menu are written in the Indonesian language. Some of them as in examples above are nasi putih, nasi tambah, nasi putih bungkus, ayam gulai, ayam goreng, ayam panggang, ayam pop, paru, rendang, ayam goreng, paru, gulai otak, gulai babat and usus etc. Linguistically, the use of Indonesian language as the names of the menu indicates a close relationship between Minangkabau and Indonesian language. In terms of business, the use of Indonesian language is aimed at improving the selling of food because the consumers of RM Minang are not only Minangkabau people but also people from all areas in Indonesia and even from abroad.

Then, transferring the concept from Minangkabau into the Indonesian language indicates that Minangkabau language contributes to enrich Indonesian or national culture. The name of the drink teh telor is translated from teh talua in Minangkabau language. Some other concepts transferred from Minangkabau into the Indonesian language are babek into babat, cancang into cincang. The Indonesian language plays a vital role in increasing and developing the culinary business of RM Minang because RM Minang spread throughout Indonesia both in cities and villages. It seems that the Indonesian language has an informational function at RM Minang. Meanwhile, Minangkabau language has a symbolic function that is the symbol of the cultural identity of Minangabau people. 
RM Minang also serves a menu using the English word as the name and label. Some examples from the above lists are sprite, juice alpokat, juice melon, juice durian, juice kopyor, juice tomat, juice sari buah, orange juice, etc. The absence of concept in Minangkabau and Indonesian language guides the owner of $R M$ Minang to use English as in the name of drinks such as sprite and orange juice. Then, the image of English as the international language, modernity and language of high status is the other reasons to put English as a part constructing the landscape of RM Minang. Thus, juice alpokat, juice melon, juice durian, juice kopyor, juice tomat, juice sari buah are used instead of jus alpokat, jus melon, jus durian, jus kopyor, jus tomat, and jus sari buah. It seems that there is code-mixing of English and Indonesia to name the drinks at RM Sederhana.

The landscape of cultural identity at RM Minang is dynamic. It varies from one RM Minang to the others. RM Asano in Lombok uses a different format of linguistic signs to name the drinks compared to RM Sederhana in Jakarta. It can be seen in Figure 4.

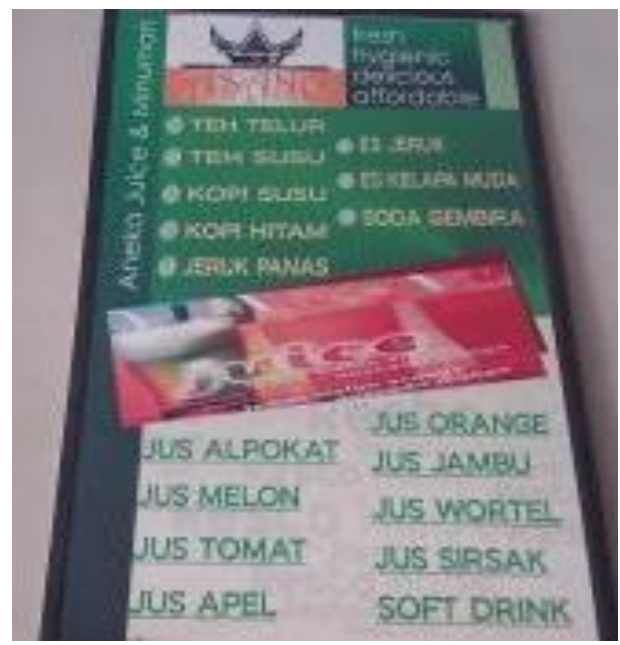

Figure 4: List of Menu at RM Asano Lombok (Source: Oktavianus, fieldwork, 2018.)

RM Asano in Lombok names the drinks using Indonesian language namely jus alpokat, jus melon, jus tomat, and jus apel. Meanwhile, RM Sederhana in Jakarta names the drinks using code mixing such as juice alpokat, juice melon, juice durian, juice kopyor, juice tomat. Minangkabau cultural identity is indicated through logo in the form of the pointed roof of Rumah Adat Minang above the word ASANO printed in red colour and capital letters. ASANO is Minangkabau cultural 
identity which means asalnya 'the origin', the dialect of Minangkabau language from Bukittinggi.

The landscape of cultural identity through linguistic signs at RM Minang are designed as attractive as possible in order to direct consumers to come and visit RM Minang. However, RM Minang in the village, in general, uses simple semiotic modes. The landscape of cultural identity of RM Minang of small scale, which is called lapau nasi is designed by using simple semiotic modes as in Figure 5.

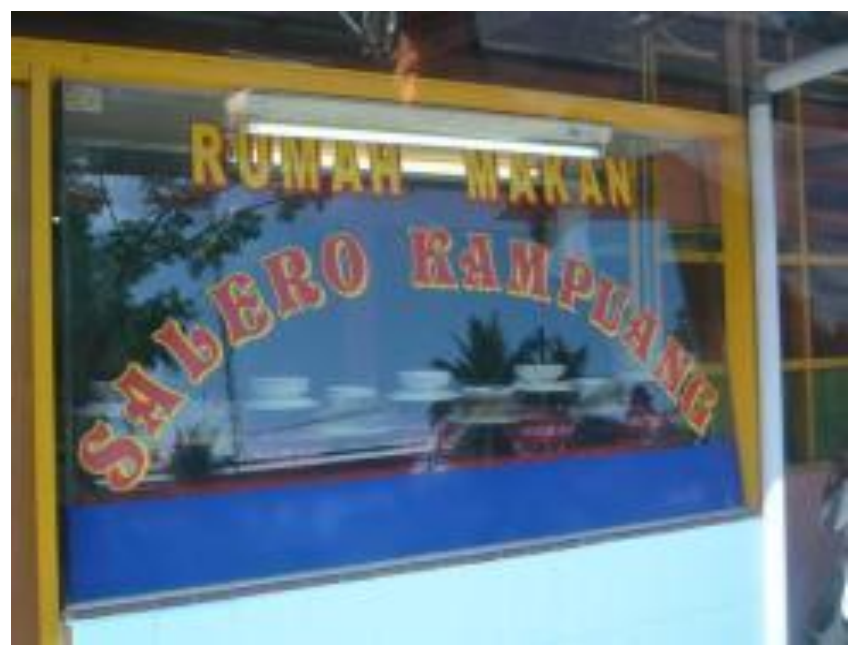

Figure 5: RM Salero Kampuang

(Source: Oktavianus, fieldwork, 2018.)

The label of RM Minang in the above picture only uses linguistic signs, namely RUMAH MAKAN and SALERO KAMPUANG. The marker of RM Minang is the name of RM Minang, SALERO KAMPUANG. The other semiotic modes used are the colours of the letters of the name of RM Minang, which are in red and yellow. This model of naming is found in some RM Minang of small scale in Minangkabau as well as in other rigions of Indonesia. These types of designs determine the class of RM Minang.

Most of RM Minang use the combination between linguistic and nonlinguistic signs as a cultural identity (see Figure 6). 


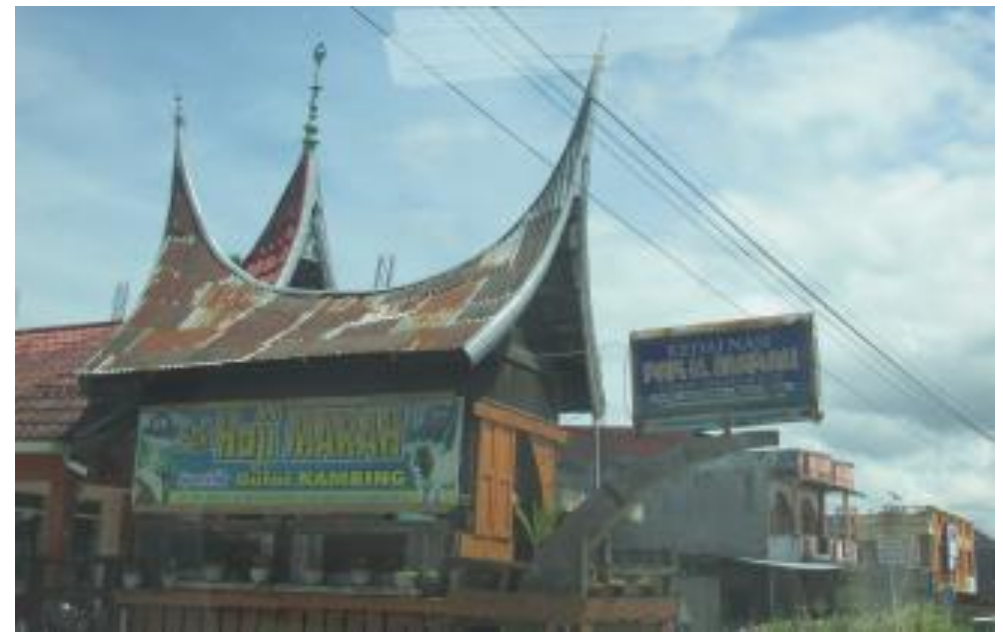

Figure 6: Kedai Nasi Pak Haji MARAH

(Source: Oktavianus, fieldwork, 2018.)

The nonlinguistic sign is the building of Rumah Adat Minang, the picture of Minangkabau woman in Minangkabau traditional dress and the picture of a goat. The linguistic signs are Kedai Nasi Pak Haji Marah and Spesifik Gulai Kambing. The nonlinguistic signs are the marker of cultural identity that this rumah makan belongs to Minangkabau ethnicity. Unlike the above picture, the cultural identity of RM Minang is presented through the design of linguistic signs, as shown in Figure 7.

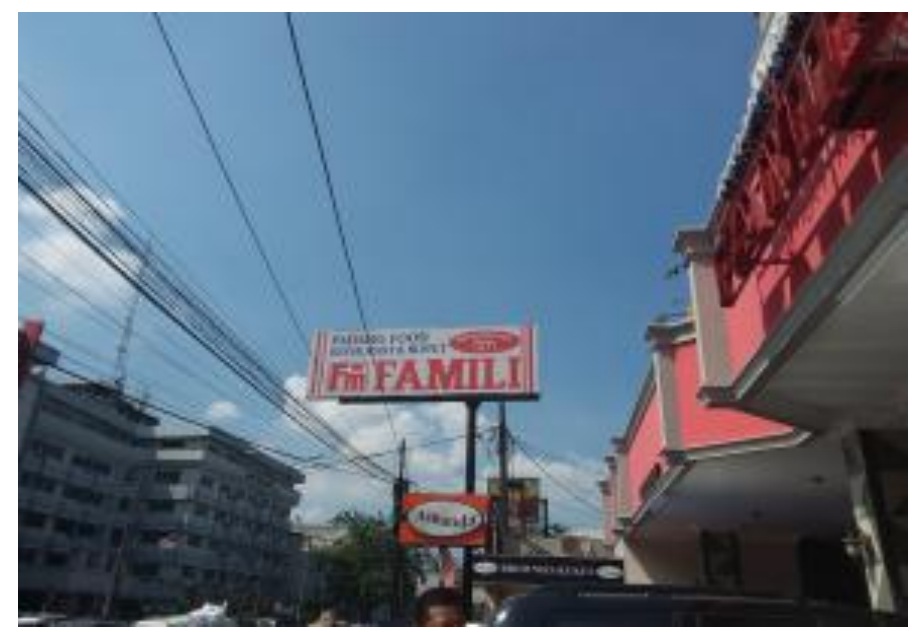

Figure 7: Padang Food. Restaurant and Buffet

(Source: Oktavianus, fieldwork, 2018.) 
The language as the name and label of RM Minang in the above picture is dominated by English, Padang Food, and Restaurant and Buffet. This restaurant is located in Medan. The use of English as the label of RM Minang indicates the presence of foreign culture at RM Minang. Geographical setting of Medan, which is close to Singapore and Malaysia triggers the owner of the restaurant to use English. However, Minangkabau cultural identity is indicated by the logo of rumah adat Minang printed at the top of abbreviated form FM (FAMILI) in red colour.

Furthermore, Gorter (2006, p. 1) states that linguistic landscape is an approach used to describe the language situation of one region or public space. The language situation includes the types of language used, whether it is monolingual, bilingual or multilingual. Based on the analysis of data collected, it seems that RM Minang uses the concept of monolingual, bilingual and multilingual as the marker of different cultural identity. The language used is Minangkabau, Indonesian, and foreign language as seen in Figure 7. However, some RM Minang uses Indonesian and English. Minangkabau language is not used as shown in Figure 8.

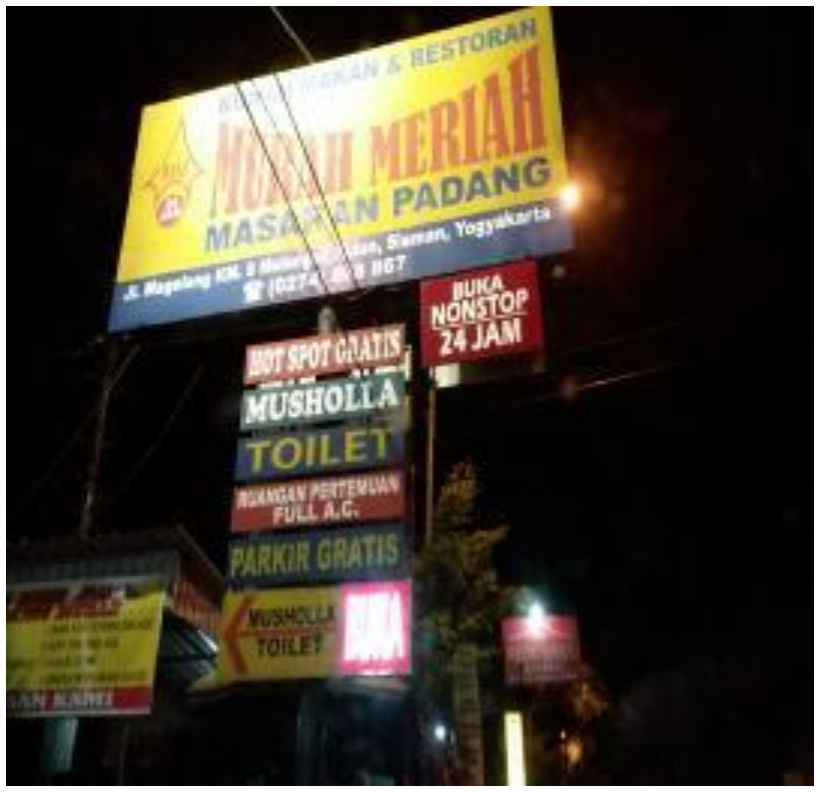

Figure 8: RM Murah Meriah in Yogyakarta (Source: Oktavianus, fieldwork, 2018.)

RM Minang in the above picture uses Indonesian and English language MURAH MERIAH and MASAKAN PADANG. The naming of RM Minang as 
MURAH MERIAH in Yogyakarta follows sociocultural setting where $R M$ Minang is located. In Yogyakarta, the price of food is not high. Thus, in order to be able to survive the concept of MURAH MERIAH is used. It seems that the naming of RM Minang to show cultural identity tend to follow physical and sociocultural setting where RM Minang is located. In Minang, many RM Minang takes the names or gala 'gelar' of people, name of a place, name of food and culinary as the name of RM Minang (Oktavianus et al., 2017). Thus, there is RM Minang named as RM PAK DATUAK (Padang Panjang), RM ACIAK (Padang), RM SAMBA LADO (Padang), RM LEMBAH ANAI (Bukittinggi), RM GULAI IKAN PUKEK (Padang). Names of RM Minang in the above examples can be used to identify RM Minang. The lexicons of English language used in the above picture are hot spot, non-stop, full AC and toilet. The landscape of RM MURAH MERIAH is the mix of national, local and foreign culture identity.

Then, the linguistic landscape of one public space or territory can serve two basic functions, namely informational and symbolic functions (Landry \& Bourhis, 1997, p. 25). As the informational function, the linguistic landscape of RM Minang inform consumers the things related to the menu and specific main menu or culinary served at RM Minang. If $R M$ Minang is located in Minangkabau, Minangkabau language is mostly used. If RM Minang is located in other cities and villages outside of Minangkabau, Indonesian language tend to be used. As the symbolic function, the landscape of RM Minang serves as a symbol of Minangkabau cultural identity as can be seen in Figure 9.

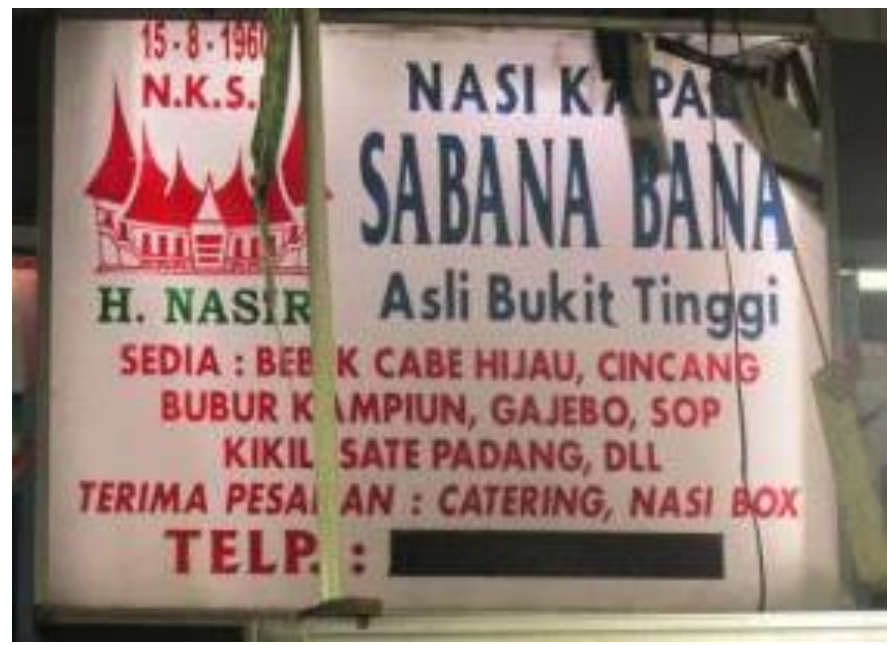

Figure 9: Nasi Kapau Sabana Bana (Source: Oktavianus, fieldwork, 2017.) 
The informational function is to inform everything related to RM Minang to the public. As the commercial shops, complete and comprehensive information are necessary for RM Minang in order to be able to survive and compete with other culinary businesses. The information provided in the above picture is shown in Table 1.

Table 1: Informational Function

\begin{tabular}{|l|l|l|}
\hline 1 & The name of RM Minang & NASI KAPAU SABANA BANA \\
\hline 2 & Year of establishing & $15-8-1960$ \\
\hline 3 & Place of origin of Owner & Bukittinggi \\
\hline & Menu & BEBEK CABE HIJAU, CINCANG, BUBUR \\
& & KAMPIUN, GAJEBO, SOP, KIKIL, SATE \\
& PADANG, dll. \\
\hline 4 & Additional information & TERIMA PESANAN, CATERING, DAN NASI \\
& & BOX \\
\hline
\end{tabular}

As the symbolic function, the landscape of RM Minang serves as Minangkabau cultural identity. Cultural identity is marked by the use of linguistic and nonlinguistic signs, as shown in Table 2.

Table 2: Symbolic Function/Cultural Identity

\begin{tabular}{|l|l|l|l|}
\hline 1 & Linguistic Signs & Nasi Kapau & $\begin{array}{l}\text { Kapau is the name of the place in } \\
\text { Bukittinggi. Nasi Kapau (Nasi with its } \\
\text { specific gulai cooked by Kapau people } \\
\text { is well known with its delicious taste. }\end{array}$ \\
\cline { 3 - 4 } & Nonlinguistic Signs & $\begin{array}{l}\text { The owner of Nasi Kapau has ever gone } \\
\text { to Mecca and assumed as the religious } \\
\text { people }\end{array}$ \\
\hline 2 & $\begin{array}{l}\text { Minangkabau people own the placement of the } \\
\text { miniature of Rumah Adat Minang as the symbol of } \\
\text { RM Minang. }\end{array}$ \\
\hline
\end{tabular}

Language reflects culture (Duranti, 1997). Culture can be identified through language. When there is a concept in one culture, and it is expressed through the native language of the culture, it means that the language serves as the cultural identity. In relation to RM Minang, there are RM Minang named RM SIKUMBANG (in Jakarta), RM CHANIAGO (in Jakarta), RM PUTRA JAMBAK (in Cirebon Java), and RM PUTRA TANJUNG (in Cirebon Java). Sikumbang, Chaniago, Jambak and Tanjung are the names of suku 'clan' in Minangkabau. If 
they are used as the names of RM Minang, they become Minangkabau cultural identity.

Every ethnic group in the world express their own cultures in their ways like food is a cultural product to unite people and has significant soft power (Hussin, H., 2018, 2019). The forms of rumah adat, the design of pakaian adat, the kinds of tools used for all activities, and the foods are different from one ethnic group to the others. In the case of RM Minang, the nonlinguistic signs used as the identity of Minangkabau cultures are dominated by the logo or the pictures of Rumah Adat Minang. Most of RM Minang in West Sumatera and other regions in Indonesia and even abroad put the logo, picture and design of Rumah Adat Minang as Minangkabau cultural identity (Figure 10).

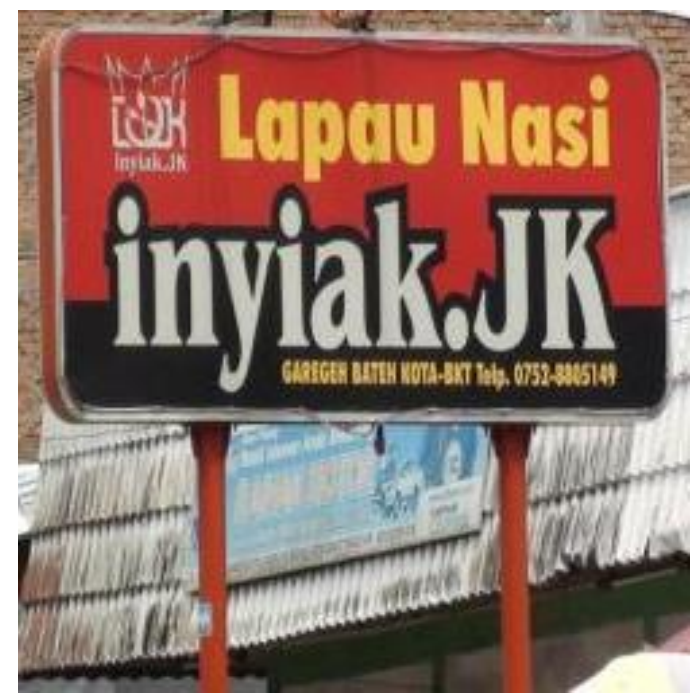

Figure 10: Lapau Nasi Inyiak JK (Source: Oktavianus, fieldwork, 2018.)

Nonlinguistic sign as Minangkabau cultural identity is indicated by putting the logo of Rumah Adat Minang in combination with the abbreviated form of IJK (Inyiak $J K$ ) in the top left corner of name plank of RM Minang with artistic design. Although RM Minang is located in Minangkabau, cultural identity is still indicated by using the logo of Rumah Adat. Then, cultural identity is also indicated by using Minangkabau language of Bukittinggi dialect, namely address term, inyiak. The word 'inyiak' is used as an address term for religious people in Bukittinggi ("Surau Inyiak", 2010). The word Inyiak can also be regarded as honorific term. The positive connotation of the word Inyiak is expected to build a positive image to RM Minang as in Figure 10. 
The picture of Rumah Adat Minang as Minangkabau cultural identity is designed in various forms. Logo of the pointed roof of rumah adat, a miniature of rumah adat, and the design of the series of letters on the name plank resembling the pointed roof of Rumah Adat Minang are among the forms of Minangkabau cultural identity. As Minangkabau cultural identity, pointed roof of Rumah Adat Minang is also modified in order to show aesthetic aspect of signs used at RM Minang. One of the examples can be seen in Figure 11.

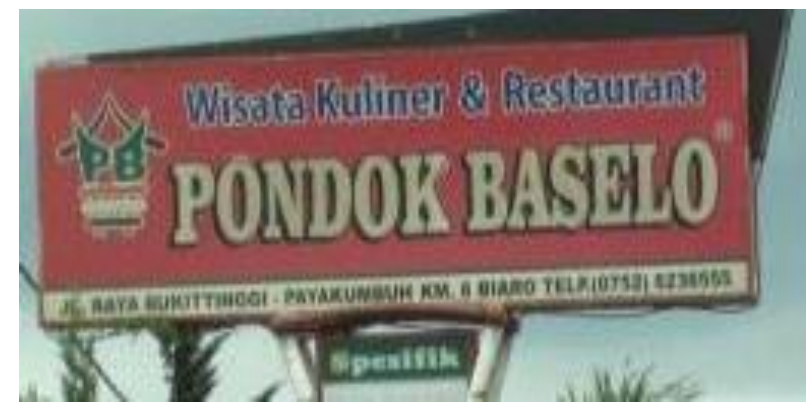

Figure 11: Wisata Kuliner \& Restaurant PONDOK BASELO

(Source: Oktavianus, fieldwork, 2018.)

There are two types of the designs of Rumah Adat Minang as Minangkabau cultural identity. First, the top side of the name plank of RM Minang is designed as it looks like the pointed roof of Rumah Adat Minang. The colour is black because in the past the roof of Rumah Adat Minang is made of Ijuak. The colour of ijuak is black. Second, PONDOK BASELO is abbreviated as PB. The design of abbreviated form of PB looks like or imitates the pointed roof of Rumah Adat Minang. The other unique form of Minangkabau cultural identity can be seen in Figure 12.

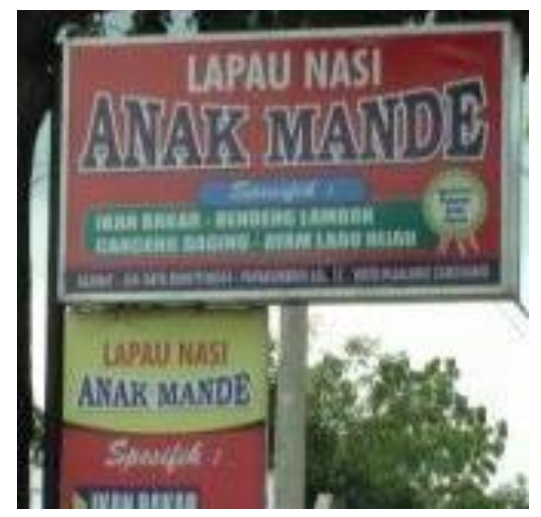

Figure 12: Lapau Nasi Anak Mande (Source: Oktavianus, fieldwork, 2018.) 
The landscape of cultural identity, is presented through the designing of linguistic signs resembling the design of the pointed roof of Rumah Adat Minang. The top side of the letters constructing the names are designed in the form of the roof of Rumah Adat Minang. The design of the letters constructed the name of RM Minang as LAPAU NASI, and ANAK MANDE resembles the pointed roof of Rumah Adat Minang which reflects Minangkabau cultural identity. Mande, ande, and andeh 'mother' are lexical variation in Minangkabau language used to address mother.

The landscape of Minangkabau cultural identity is also indicated through the form or construction of the building used as RM Minang. The building of $R M$ Minang imitates or follows the style of Rumah Adat Minang. The building is modified as RM Minang by adding the roof arch of Rumah Adat Minang in the front part of the building or gate of the building as in the following example, Figure 13.

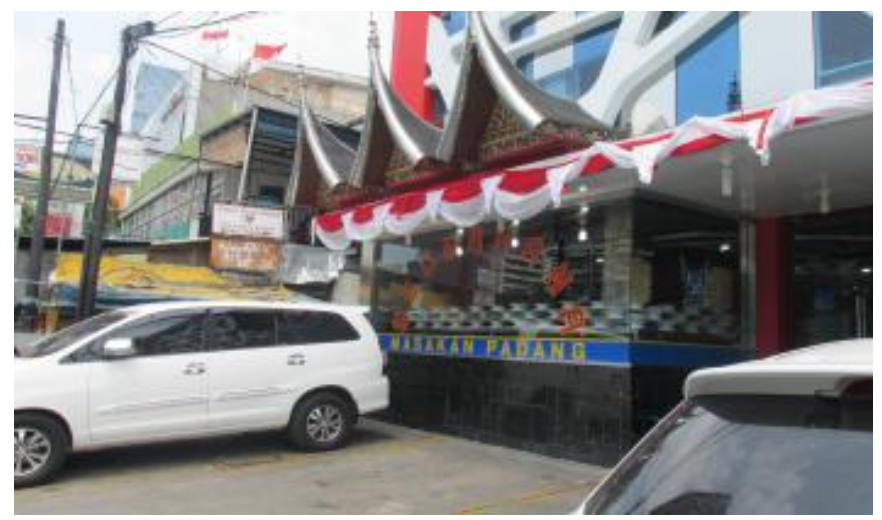

Figure 13: RM SEDERHANA Jakarta

(Source: Oktavianus, fieldwork, 2018.)

The above picture is RM SEDERHANA in Jakarta. The landscape of cultural identity is presented through the design of the pointed roof of Rumah Adat Minang in the front part of RM SEDERHANA. Logo of RM SEDERHANA derived from the pointed roof of Rumah Adat Minang is created. It already has the copyright so that Minangkabau cultural identity of all RM SEDERHANA in Indonesia and even abroad will be the same (see Figure 14).

It is nice and interesting to see the existence of the building of Minangkabau style of RM Minang among other buildings belonging to another ethnic group in the city in Sumatera, Java, Bali, Lombok, and Papua. Quick identification can be made by looking at the style of the roof arch if people want to eat at RM Minang, especially outside of Minangkabau land. 


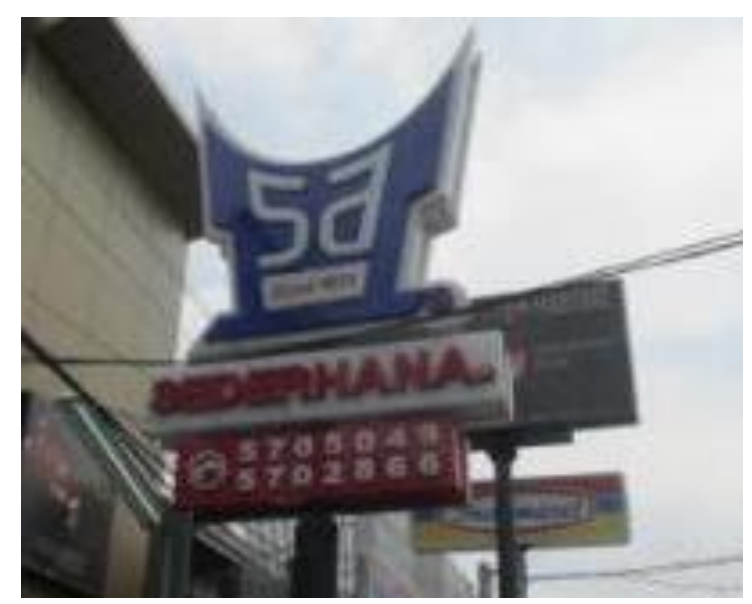

Figure 14: Logo of RM Sederhana Jakarta (Source: Oktavianus, fieldwork, 2018.)

\section{Conclusion}

As stated in the research question of this study, this research is focusing on the landscape of cultural identity at RM Minang. The two main themes investigated are the forms and designs of cultural identity. Based on the analysis of the data by referring to the concept of cultural identity, linguistic, nonlinguistic and multimodal approach, five findings can be formulated at the end of this research. First, the marker of cultural identity is always present at RM Minang. Second, the landscape of cultural identity at RM Minang is built up by integrating different semiotic modes consisting of linguistic and nonlinguistic signs (logo and pictures of Rumah Adat Minang). Third, the sign system used at RM Minang is the combination of Minang, national and foreign cultural identity.

It is marked by the use of Minang, Indonesian and English language. Fourth, the forms and designs of cultural identity at RM Minang identity are name designs resembling to the pointed roof of Rumah Adat Minang, logos in the form of Rumah Adat Minang, and RM Minang resembles to Rumah Adat Minang itself. Fifth, the needs to survive and develop culinary business makes $R M$ Minang to become accommodative to other cultures. It is reflected through the use of linguistic signs of Indonesian and foreign languages.

Based on the findings, as stated above, it can be concluded that $R M$ Minang is a very strategic culinary institution to develop and maintain Minangkabau culture. Wherever RM Minang is present, the element of Minangkabau cultural identity is also present. 


\section{Acknowledgements}

The author would like to thank the owner of RM Minang in Indonesia for facilitating this research, especially the permission to do an interview and to photograph RM Minang of their own. The author is also indebted to Asosiasi Rumah Makan Minang in Bali for the kindness to facilitate focused group discussion to get the information about RM Minang. The author would also like to thank the committee of the 12th International Conference on MalaysiaIndonesia Relations (PAHMI-12) for publishing this article.

\section{References}

Amer, F., \& Obeidat, R. (2014). Linguistic landscape: A case study of shop signs in Aqaba City, Jordan. Asian Social Science, 10(18), 246-252.

Amir, M. S. (1997). Adat Minangkabau: Pola dan tujuan hidup orang Minang . Jakarta: Mutiara Sumber Widya.

Coluzzi, P. (2012). The linguistic landscape of Brunei Darussalam: Minority languages and the threshold of literacy. Southeast Asia: A Multidisciplinary Journal, 12, 1-16.

Crystal, D. (1998). The Cambridge encyclopedia of language. Cambridge University Press.

Crystal, D. (2000). Language death. Cambridge: Cambridge University Press.

Duranti, A. (1997). Linguistic anthropology. Cambridge: Cambridge University Press.

Fekede, A., \& Gemechu, T. (2016). An analysis of linguistic landscape of selected towns in Oromia: An ethnolinguistic vitality study. Journal of Languages and Culture, 7(1), 1-9.

Gorter, D. (Ed.). (2006). Linguistic landscape: A new approach to multilingualism. Clevedon: Multilingual Matters.

Hussin, H. (2019). Buwas Kuning (Yellow Rice) and its Symbolic Functions Among the Sama-Bajau of Malaysia. SAGE Open, 1-13.

Hussin, H. (2018, October-December). Gastronomy, tourism and the soft power of Malaysia. SAGE Open, 1-11.

Kress, G., \& Van Leeuwen, T. (2001). Multimodal discourse: The modes and media of contemporary communication. London: Arnold.

Landry, R., \& Bourhis, R. Y. (1997). Linguistic landscape and ethnolinguistic vitality: An empirical study. Journal of Language and Social Psychology, 16(1), 23-49. 
Naim, M., Paragoan, W., Asril, Z., \& Rasyid, F. (1987). Sistem pengelolaan restoran Minang: Sebuah prototipe sistem ekonomi Pancasila. Jakarta: Penerbit Yayasan Obor Indonesia.

Oktavianus, Revita, I., \& Anwar, K. (2017, 18-19 October). Linguistic landscape of Rumah Makan Minang: A preliminary analysis of how the names of Rumah Makan Minang are created and cultural values are reflected. Paper presented at the International Conference on Language and Arts, Padang, Indonesia.

Oktavianus, \& Revita, I. (2013). Kesantunan dalam bahasa Minangkabau. Padang: Minangkabau Press.

Oktavianus. (2019, 10-11 July). The roles and designs of written English at public places. Paper presented at the 4th International Seminar on Linguistics (ISOL-4), Padang, Indonesia.

Spolsky, B. (2009). Prolegomena to a sociolinguistic theory of public signage. In E. Shohamy \& D. Gorter (Eds.), Linguistic landscape: Expanding the scenery (pp. 25-39). New York: Routledge.

Sudaryanto. (2018). Metode dan aneka teknik analisis bahasa. Yogyakarta: Sanata Dharma University Press.

Surau Inyiak. (2010, 4 April). Retrieved from surauinyiak.wordpress.com

\section{Appendix}

\section{Local term and translation}

\section{Note related to the translation of local terms:}

1. Some concepts cannot be translated into English because they are cultural words and Proper Names.

2. The concepts which are possible to translate has already been changed/translated in this article.

Rumah makan 'restaurant'

(The term "Rumah makan" in this research is not really the same as restaurant because research is not only done to restaurant but also to small scale "Rumah Makan")

Rumah Makan Minang 'Minang Restaurant'

Rumah Gadang 'Traditional House'

Rumah Adat 'Traditional House' 
(In Minang, Rumah Gadang means Rumah Adat 'Traditional House')

RUMAH MAKAN and SALERO KAMPUANG

(Proper name)

Kedai Nasi Pak Haji Marah

(Proper name)

MURAH MERIAH and MASAKAN PADANG 'the cheapest and Padang food'

Istano Pagar Ruyung (Proper Name and it is not translated)

RM Sederhana 'Sederhana Restaurant'

TERIMA PESANAN, CATERING, DAN NASI BOX 'catering'

Mande, ande 'mother'

Andeh 'mother'

pakaian adat 'traditional custom'

\section{Menu}

dendeng balado 'slice thin beef in chili'

dendeng batokok 'thin crispy beef'

gulai ati 'gulai of cow liver or cow liver curry'

nasi putih 'plain'

nasi tambah 'additional rice'

nasi putih bungkus 'wrapped plain rice'

ayam gulai 'chicken curry'

ayam goreng 'fried chicken'

ayam panggang 'grill spicy chicken'

ayam pop 'pop chicken'

paru 'fried cow lung'

rendang 'beef simmered in coconut milk and spicy'/'beef rendang'

ayam goreng 'fried chicken'

paru 'fried cow lung'

gulai otak 'gulai of cow brain'

gulai babat 'cow tripes curry' or 'cow tripe gulai'

(the concept of gulai is not really the same as curry in English')

usus 'gulai of cow intestines'

teh telor 'mixture of tea and egg'

teh talua 'mixture of tea and egg'

babek, babat "cow tripes curry' or 'cow tripe gulai'

cancang, cincang 'meat curry and cow internal'

juice alpokat 'avocado juice'

juice melon 'melon juice'

juice durian 'durian juice' 
juice kopyor 'kopyor juice' juice tomat 'tomato juice' juice sari buah 'sari buah juice' orange juice

juice alpokat 'avocado juice'

lapau nasi

Spesifik Gulai Kambing ‘specific goat curry'

rumah makan 'restaurant'

rumah adat Minang 'Minang traditional house'

gala 'gelar'/'title'

NASI KAPAU SABANA BANA 'the real Kapau rice'

BEBEK CABE HIJAU 'duck curry with green chili'

CINCANG 'meat curry and cow internal'

BUBUR KAMPIUN 'porridge made from rice flour mixed with brown sugar'

GAJEBO 'cow fat curry'

SOP 'soup'

KIKIL 'cow foot tendon curry'

SATE PADANG 'Padang satay'

Nasi Kapau 'Kapau rice'

inyiak

LAPAU NASI and ANAK

Date Received: 11 March 2019 Date of Acceptance: 15 November 2019 